\title{
TRANSMISSION OF ASPARAGUS VIRUS 2 IN AN ASPARAGUS CROP
}

\author{
M.V. JASPERS and M.N. PEARSON ${ }^{1}$ \\ Plant Science Dept., Lincoln University, Canterbury, New Zealand \\ ${ }^{l}$ School of Biological Sciences, University of Auckland, Auckland, New Zealand
}

\begin{abstract}
Mechanisms of asparagus virus 2 (AV2) transmission were investigated in an asparagus field trial. Initially each row had two AV2infected plants in the middle and eight AV2-free plants on either side. During 1992-1995, spears were hand-harvested, each row in one direction only, but half the block with the prevailing northerly wind and half against it. Spread of AV2 was predominantly in the direction of cutting, with AV2 incidence in plants cut after the AV2-source plants reaching $96 \%$ by 1995. In areas cut prior to the AV2 source plants there was some spread of the virus, mainly into female plants and into plants downwind of the source plants, indicating the possibility of a wind-assisted transmission mechanism.
\end{abstract}

Keywords: asparagus, asparagus virus 2, mechanical transmission, pollen transmission

\section{INTRODUCTION}

Virus diseases of crops assume major economic significance when they become widespread as a result of numerous secondary cycles of replication, transmission and infection. Because the different mechanisms of virus transmission have different efficacies and may result in different spatial and temporal patterns of diseased plants within crops (Gibbs and Harrison 1976), a study of the patterns of infected plants can give an insight into the method by which a virus is spread.

Asparagus virus 2 (AV2) is known to be transmitted in seed (Mink and Uyeda 1977), therefore this is the most likely source of the virus in new asparagus plantings. Since the incidence of AV2 has been shown to be greater in older asparagus plantings (Hartunget al. 1985; Jaspers and Falloon 1996) and to increase by as much as $30 \%$ per annum in an established planting (Evanset al. 1990), it is clear that secondary spread of AV2 must occur. Mechanisms for secondary spread of AV2 in the field have not been investigated. However, under experimental conditions it has been shown that transmission of the virus can occur by mechanical means but not by aphids (Mink and Uyeda 1977; Evans and Stephens 1989). It is therefore probable that field transmission occurs by infected sap on cutting knives. In addition, because AV2 virions have been found on the exine of asparagus pollen, and rubinoculation with washings of this pollen have resulted in transmission of the virus to Chenopodium quinoa (Evans and Stephens 1988), spread of AV2 in the field may also be by infected pollen coming into contact with uninfected plants (horizontal pollen transmission). The aims of this study were to discover whether AV2 was transmitted mechanically in asparagus crops on cutting knives and also whether pollen-borne AV2 was a possible source of infection in crops.

\section{METHODS}

Asparagus plants were raised in a greenhouse from AV2-free seed of the cultivar UC157. Immature, unfurled fern tips of 12-15 week old plants were tested with indirect ELISA (Jaspers and Falloon 1996) and found to be free from AV2 infection. The plants designated to be the sources of the virus in the trial, were rub-inoculated with AV2infected asparagus sap onto stems and cladophylls of young shoots (Evans and Stephens 1988), on several occasions before and after planting. All plants were set out, at 24 weeks

Proc. 50th N.Z. Plant Protection Conf. 1997: 84-88 
old, in a trial at Lincoln University in spring 1990. Newly emerged shoots of the AV2designated plants were tested for the presence of the virus by indirect ELISA during the 1991/92 growing season. Reinoculation and ELISA testing was repeated until all AV2designated plants tested positive for the virus in at least two of the three shoots collected at a single sampling.

In the trial layout (Fig. 1) two AV2-infected plants were positioned in the middle of each plant row with eight AV2-free plants on either side. To investigate the possibility of mechanical transmission by transfer of AV2-infected sap on cutting knives, cutting was in one direction only over the duration of the trial, and comparisons were made between incidences of AV2 in plants cut before the AV2 source plants and those cut after the source plants. In addition, the trial was divided in two sectors with repect to wind direction. One half of the trial was cut in the same direction as that of the prevailing northerly wind (during periods of pollen release), and the other half was cut against the prevailing wind, creating blocks which were upwind and downwind of AV2 source plants, both for plants cut prior to source plants and those cut after source plants (Fig. 1). The effect of natural AV2 transmission in all directions, could therefore be separated from the effect of transmission by movement of AV2-infected sap on cutting knives.

Replicates in this trial were the 12 rows of plants for each treatment. Cutting of each row commenced with a virus-free knife, which had been soaked in the $30 \mathrm{~g} / \mathrm{litre}$ trisodium orthophosphate for 1-2 minutes. The harvesting periods were for three and six weeks in 1992 and 1993 respectively, and for nine weeks in 1994 and 1995. During annual harvests of 1993-1995, five spear butts of 20-40 mm were collected from each plant and stored at $-20^{\circ} \mathrm{C}$, until they were individually tested for AV2, by indirect ELISA. The ELISA threshold chosen for determining AV2 infection status was $\bar{x}+4$ s of the three healthy samples analysed in each ELISA microtitre plate, because this threshold had been shown to eliminate false positives (Jaspers and Falloon 1996). Because concentrations of AV2 virions in asparagus plants were known to increase after infection (Jaspers unpubl. data), any plants awarded false negative scores by this threshold were likely to be awarded positive scores the following year.

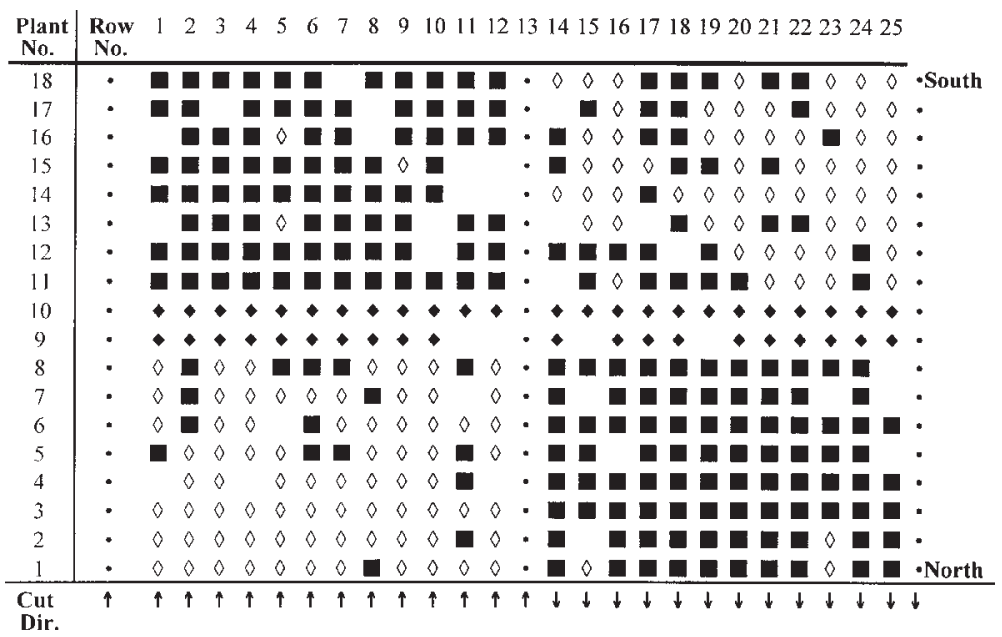

FIGURE 1: Trial plan showing the cutting directions and the positions of AV2infected source plants $\rightarrow$ amongst a lattice composed entirely of AV2free plants in 1992. Changes in plant status are shown as empty cells where plants had died and asn where plants were infected with AV2 by 1995. 
The resultant spatial and temporal patterns of infection in the trial were statistically analysed in two ways: (1) Plants were scored according to their AV2 infection status (plants were determined to be AV2-infected only if one or more spears tested positive by the above threshold) and data were analysed by Chi-square with Yates correction applied when the number of expected values was less than five; (2) Plants were scored for their severity of infection by allocating a score of 1 to samples which reached the ELISA threshold $\mathrm{x}+4 \mathrm{~s}$, (equivalent to $1.1 \mathrm{x}-1.5 \mathrm{x}$ ) and allocating a score of 2 to samples which reached the ELISA threshold $\bullet 2 x$. The sums of sample scores were recorded for each plant and data were analysed by ANOVA.

\section{RESULTS AND DISCUSSION}

For each year of the trial, the AV2 infection status of each plant was determined and the data analysed with respect to plant placement (i.e. whether cut before or after AV2 source plants) wind direction (i.e. whether plants were upwind or downwind of AV2 source plants) and plant gender. AV2 infection scores were analysed for the same effects and also for plant position within rows. Fig. 1 shows the layout of the trial and the change in AV2 status of plants between 1992 and 1995.

Incidence of AV2 infected plants increased annually; by $1995,96.5 \%$ of the plants were infected in areas cut after AV2 source plants, compared to $26.0 \%$ in areas cut before. These trends were apparent and differences were significant $(\mathrm{P}<0.05)$ throughout 1993-1995 by both methods of analysis (using AV2 incidence and AV2 infection scores). It can therefore be concluded that transmission of AV2 occurred by mechanical transfer of AV2 virions in asparagus sap on cutting knives.

The effects of wind direction and plant gender on incidence of AV2-infected plants are illustrated in Fig. 2. Overall, the effect of wind direction on AV2 incidence was significant $(\mathrm{P}<0.05)$ only in 1995 and only in the areas where plants were cut before the AV2 source plants, where there was $124 \%$ higher incidence of infected plants downwind than upwind of the source plants. This indicated that transmission was initially by some form of wind-assisted transport, although subsequent harvesting of these plants would



FIGURE 2: Numbers of AV2-infected plants in areas cut before and after AV2 source plants, during 1992-1995, showing effects of plant gender and wind direction, i.e. areas upwind or downwind of AV2 source plants. 
have caused transmission of AV2 by infected sap on cutting knives. Since asparagus pollen is not wind-dispersed but is carried by a variety of insects, including bees and flies, (P. Falloon pers. comm.) it seems possible that their movement is assisted by the prevailing northerly wind and that this accounts for the increased incidence of AV2 in plants downwind of the source plants.

Effects of plant gender on incidence of AV2 infection were only significant $(\mathrm{P}<0.05)$ in areas where plants were cut before AV2 source plants, resulting in $69 \%$ higher numbers of infected female plants than male plants in 1995. This suggests that female plants may be more susceptible to infection by AV2 virions, as has been found to be the case for Fusarium root and crown rots (Falloon 1982), or that pollen-borne AV2 virions may infect female plants during fertilisation. In areas where plants were cut after the source plants, effects of wind direction and plant gender were not significant $(\mathrm{P}>0.05)$, possibly because these effects may have been masked by the stronger effects of AV2 transmission by cutting.

Results from analysis of AV2 infection scores by ANOVA were similar to results from the Chi-square analysis using AV2 infection status, with respect to plant gender, wind direction and whether plants were cut before or after AV2 source plants. In addition, the ANOVA showed that AV2 infection scores of plants were significantly different $(\mathrm{P}<0.05)$ at the different plant positions within rows, in areas where cutting was prior to source plants in 1993, and in areas cut after source plants in 1995. In both cases AV2 infection scores were higher for plants closer to the source plants than for plants further away (Fig. 3).

Although transmission of AV2 in the direction of cutting was rapid and extensive, it can be seen from Fig. 1 that occasional plants did not become infected. Spears were not cut from every plant on every harvest occasion because spear production was irregular and total spear numbers were sometimes too few. Therefore, during any daily harvest event, groups of plants could have been skipped over, creating gaps in possible transmission sequences. This could have resulted in uneven distributions of infected plants along rows. Because AV2 infection scores reflect many infection events, a declining infection gradient away from source plants might be expected. In Fig. 3 a small gradient in mean infection scores is evident but because the rows were not long enough this could not be demonstrated conclusively. Fig. 1 shows that there was some clustering of infected plants within rows. However because of the strong effect of AV2 transmission by cutting and the interrupted nature of the harvest sequence, the spatial and temporal distributions of AV2-infected plants were not considered suitable for further analysis (Jeger et al. 1987).

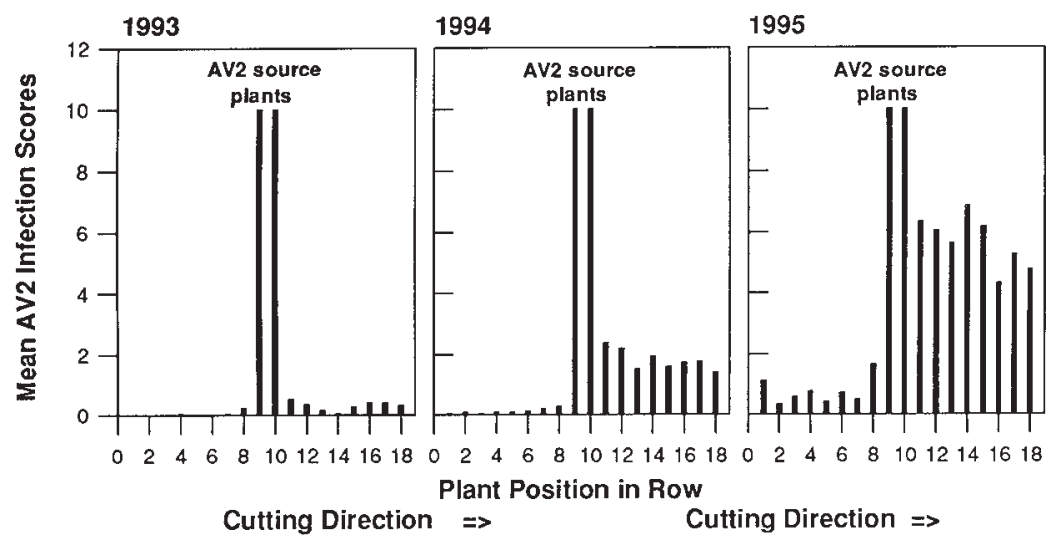

FIGURE 3: Mean AV2 infection scores of plants, by plant position within rows, during 1993-1995. 
Since yield in asparagus crops can be significantly reduced by AV2 infection (Jaspers 1996), it is important that growers use cultural practices which prevent the introduction and subsequent spread of the disease within asparagus plantings. Use of AV2-free planting material in establishing crops can prevent primary introduction, but once the virus is introduced into a crop it would not seem to be possible to prevent further spread by sap on cutting knives, since disinfection of knives between plants would be too timeconsuming to be an economic option.

The preliminary evidence from this trial indicates that pollen-borne AV2 may be a source of infection for healthy plants but for conclusive evidence of this possibility further investigations are required. Pollen transmission of AV2 may be of serious concern to growers, not only because it may increase rates of secondary spread of the virus within crops but more importantly, because it could allow introduction of the virus from outside sources. Techniques for prevention of pollen transmission will depend upon the mechanism by which the AV2 virion is transmitted to and enters the vegetative plant tissues. For a number of viruses which are borne on pollen surfaces, successful transmission of the viruses to plants has been shown to depend upon the presence of thrips (Mink 1992). Since a number of thrips species occur commonly on asparagus plants (Townsend and Watson 1984) and since both thrips and asparagus pollen can be transported by bees (Mink 1992), application of pesticides active against thrips may prove to be an effective means of preventing infection. If the pollen-borne AV2 virion is found to only infect female plants during fertilisation then use of all-male asparagus cultivars may prevent pollen-borne introduction of AV2 into an asparagus planting.

\section{ACKNOWLEDGEMENTS}

We wish to thank Peter Falloon of AsparaPacific, Christchurch for much-needed advice on asparagus-growing and for the gift of asparagus seed, also Paul Mulcock for editing assistance and the New Zealand Asparagus Research Council for funding this study.

\section{REFERENCES}

Evans, T.A., DeVries, R.M., Wacker, T.L. and Stephens, C.T., 1990. Epidemiology of asparagus viruses in Michigan asparagus. Acta Hort. 271: 285-290.

Evans, T.A. and Stephens, C.T., 1989. Increased susceptibility to Fusarium crown and root rot in virus-infected asparagus. Phytopath. 79: 253-258.

Evans, T.A. and Stephens, C.T., 1988. Association of asparagus virus II with pollen from infected asparagus (Asparagus officinalis). Plant Dis. 72: 195-198.

Falloon, P.G., 1982. The need for asparagus breeding in New Zealand.N.Z. J. Exp. Agr. 10: 101-109.

Gibbs, A. and Harrison, B., 1976. Pp 183-204 In: Plant Virology: The Principles. Edward Arnold, London, Great Britain. 292 pp.

Hartung, A.C., Evans,T.A. and Stephens, C.T., 1985. Occurrence of asparagus virus II in commercial asparagus fields in Michigan. Plant Dis. 69: 501-504.

Jaspers, M.V., 1996. Effect of asparagus virus 2 on yield of Asparagus officinalis. Acta Hort. 415: 383-386.

Jaspers, M.V. and Falloon, P.G., 1996. Survey of asparagus crops in New Zealand for asparagus virus 2. Acta Hort. 415: 301-307.

Jeger, M.J., Kenerley, C.M., Gerik, T.J. and Koch, D.O., 1987. Spatial dynamics of Phymatotrichum root rot in row crops in the Blackland region of north central Texas. Phytopath. 77: 1647-1656.

Mink, G.I., 1992. Ilarvirus vectors. Adv. Dis. Vec. Res. 9: 267-281.

Mink, G.I. and Uyeda, I., 1977. Three mechanically-transmissible viruses isolated from asparagus in Washington. Pl. Dis. Rep. 61: 398-401.

Townsend, R.J. and Watson, R.N., 1984. Stand management of asparagus for control of thrips. Proc. N.Z. Weed and Pest Control Conf. 37: 151-155. 